\title{
Barnesentrert pedagogikk i barnehagen
}

\author{
Av Liv Ingrid Aske Håberg
}

Artikkelen undersøker kva som kjenneteiknar barnesentrert pedagogikk i barnehage og samfunn, og kva konsekvensar ei slik pedagogisk retning kan ha for barn $i$ vår tid som ofte blir omtala som den postmoderne tidsalderen. Barnesentrert pedagogikk blir for det første omhandla ved å bli definert teoretisk, knytt til danningsteoriar og den didaktiske trekanten. For det andre blir det vist til historiske trekk ved samfunn og kultur som kan ha støtta opp under utvikling av denne typen pedagogikk $i$ barnehagen. For det tredje presenterer artikkelen nyare empirisk forsking som problematiserer om pedagogiske retningar førekjem i reindyrka form eller som hybridar. Til saman legg dette grunnlag for drøfting av om barnesentrert pedagogikk både underbygger narsissistiske tendensar og gir barn eit for stort ansvar for eiga utvikling og læring.

Nøkkelord: danning, narsissisme, sjølvverksemd, hybrid pedagogikk, didaktikk, barnehage

LIV INGRID AsKE HÅBERg, f. 1958, førsteamanuensis, Avdeling for humanistiske fag og læerarutdanning, Høgskulen i Volda. E-post: lih@hivolda.no

\section{INNLEIING}

Barnehagen har dei siste åra blitt del av ein nasjonal utdanningsstrategi og har gått frå å vere eit tilbod for fåtalet til eit velferdsgode for alle barn og foreldre. Samfunnsmandatet, slik det kjem til uttrykk i barnehagelov og rammeplan, understreker barnehagen sitt ansvar som pedagogisk institusjon til å støtte barnas danningsprosessar gjennom omsorg, leik og læring (Kunnskapsdepartementet 2005, 2017). På trass av dette finn ein lite forsking på kva type pedagogikk barna møter i barnehagen, og kva konsekvensar ulike pedagogiske retningar kan ha for barna. Denne artikkelen unders $\emptyset$ ker difor spesifikt barnesentrert pedagogikk fordi denne retninga er ein sentral del av barnehagen sin pedagogiske tradisjon med røter tilbake til Fröbel, som er barnehagens grunnleggar (Broström 2004). ${ }^{1}$

1 Artikkelen er ein revidert versjon av mi prøveforelesing for graden $\mathrm{PhD}$ ved Det utdanningsvitenskapelige fakultet, UiO 17. juni 2015. Oppgitt tema var korleis den barnesentrerte pedagogikken blir utfordra av omgrep som læring, didaktikk og postmoderne perspektiv. Avhandlinga har tittelen «Didaktisk arbeid i barnehagen: Kvalitativ studie av korleis assistentar og barnehagelærarar planlegg, gjennomfører og vurderer samlingsstund og femårsklubb». Avhandlinga er i etterkant omarbeidt til fagboka «Kvardagslivets didaktikk: ansvar og arbeidsdeling» (Håberg 2016).

Prismet - IKO-Forlaget 2017

Tilgjengelig på https://journals.uio.no/index.php/prismet. Publisert under CC BY-NC 4.0. Fagfellevurdert 
Omgrepet barnesentrert pedagogikk kan forståast på fleire måtar. Ein kan for eksempel tenke seg at sidan det er barnehagen ein snakkar om, så vil barnesentrering vere sjølvsagt: I barnehagen finn ein små barn som treng at personalet dekker basale behov (Drugli 2014). Ifølge barnehagelov og rammeplan skal barndomen bli anerkjent som verdifull og barn bli sett på som fullverdige menneske med rett til medverknad (Kunnskapsdepartementet 2005, 2017). Idealet er å løfte fram barndomen sin eigenverdi og omtale barn primært som «beings» og ikkje berre som «becomings» (Bae 2016).

Som ei følgje av dette er eit sterkt fokus på barna sine rettar og behov viktig og sentralt i barnehagen, men omgrepet barnesentrert pedagogikk treng likevel ikkje vere eit eintydig positivt omgrep. Som døme åtvara Erling Kristvik, rektor ved Volda lærarhøgskule frå 1930 til 1946, mot ein for einsidig barnesentrert pedagogikk i skulen. Han meinte ifølge Solberg (2002) at i staden må pedagogen sørge for at barnet møter noko utanfor seg sjølv. Er dette ein relevant kritikk også for barnehagen i vår tid? Og er det kanskje trekk ved kulturen i notida som gjer det enda meir naudsynt med ei kritisk vurdering av barnesentrert pedagogikk? Sameleis kan ein spørje seg om barnesentrert pedagogikk støtter opp om narsissistiske tendensar i kulturen. Å gjere greie for kva barnesentrert pedagogikk er for noko og peike på mulige kritikkar av denne type pedagogikk er difor sentralt i artikkelen. Særtrekk og utfordringar blir såleis unders $\emptyset$ kt gjennom problemstillinga: Kva kjenneteiknar barnesentrert pedagogikk i barnehagen, og kva konsekvensar kan denne pedagogiske retninga ha i vår tid?

Problemstillinga blir belyst gjennom tre tilnærmingar. For det første ved å teoretisk definere barnesentrert pedagogikk slik at forståing av omgrepet blir forankra i strukturar og modellar med tilknyting til åndsvitskapleg pedagogikk og danningsteoretisk didaktikk (Gundem 1975). For det andre blir problemstillinga belyst gjennom eit blikk for historisitet. Pedagogiske retningar oppstår og blir vidareført i historiske kontekstar, og både strøymingar i kultur og samfunn og frøbelsk pedagogikk kan ha lagt føringar for ein barnesentrert pedagogikk. ${ }^{2}$ Den tredje tilnærminga til problemstillinga er av empirisk karakter og viser til forsking knytt til gjennomføring av vaksenleia aktivitetar i barnehagen (Håberg 2015). $\AA$ unders $\emptyset$ ke og drøfte samanhengar mellom empiriske funn og pedagogiske retningar er eit lite utforska område på barnehagefeltet.

Til saman legg dei tre tilnærmingane grunnlag for å drøfte kva konsekvensar barnesentrert pedagogikk i barnehagen kan ha i vår tid, som ofte blir kalla den postmoderne tidsalderen. Med postmoderne er meint trekk ved vår samtid, som oppløysing av tradisjonar og forpliktingar, som skaper andre rammer rundt barns oppvekst enn tidlegare (Hargreaves 1996).

2 Artikkelen går i liten grad nærare inn på korleis transformasjon av pedagogiske idear kan skape kløft mellom formuleringsarenaen og realiseringsarenaen (Lindensjö \& Lundgren 2000). 


\section{TeOretiske perspeKtiv}

Danningsteoretisk didaktikk har sin bakgrunn i åndsvitskapleg teori med danningsomgrepet som eit heilskapleg og samanbindande omgrep og som det sentrale for pedagogisk intensjonalitet (Gundem 1998). Eg har difor valt å definere barnesentrert pedagogikk med utgangspunkt i den didaktiske trekanten som er ein danningsteoretisk grunnmodell tilhøyrande didaktikkens arvegods (Hopmann 1997; Künzli 2000). Danning blir av Gundem (1998: 145) definert som «at det enkelte mennesket skal nå frem til ansvarlig handling ut fra egne indre motiv og gjennom å ha tilegnet seg de felles verdier og normer samfunnet anerkjenner». Utvikling av det indre mennesket og forplikting overfor samfunn og kulturarv blir difor viktige faktorar i danningsprosessen.

\section{Den didaktiske trekanten}

Den didaktiske trekanten har som premiss at ein pedagogisk situasjon føreset tre faktorar: barn, innhald og personale. Barn er ein eigen faktor i modellen, og det understrekar barnet som subjekt med eit individuelt og autentisk sjølv, samtidig som dette sjølvet også er situert gjennom intersubjektive samanhengar (Østrem 2012). Innhald er på toppen av modellen og har ein predominans i forhold til faktorane personale og barn som subjektets sosialiseringsobjekt (Hopmann 1997). Personalet, som representant for vaksengenerasjonen, har ei vesentleg rolle i danningsprosessar hos den oppveksande slekt (Uljens og Mielityinen 2004). Personale tyder i denne samanhengen både barnehagelærarar og assistentar, sidan begge yrkesgruppene arbeider direkte med barna.

Dynamikken mellom faktorane $\mathrm{i}$ den didaktiske trekanten er sentral slik at ulike pedagogiske retningar kjem til uttrykk gjennom vektlegging og forståing av spenningsfeltet og samspelet mellom personale, barn og innhald. Som døme kan det å legge stor vekt på personalet som formidlar eit innhald, leie over i formidlingspedagogikk (Gundem 1998). Innhaldet blir då tillagt større vekt enn interesser og erfaringar til barnet, og personalet får rolla å implementere eit innhald som er planlagt og gitt på førehand.

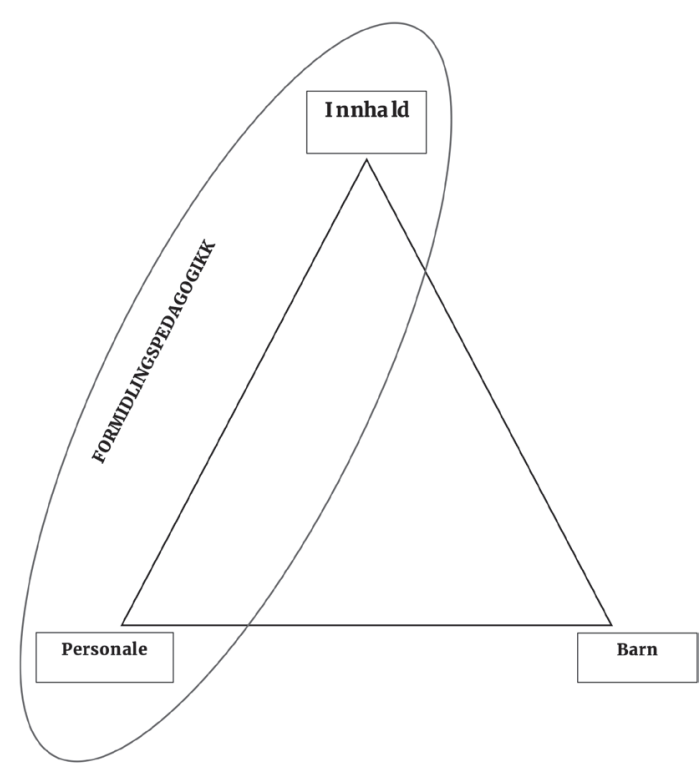

Figur 1 Formidlingspedagogikk med utgangspunkt $i$ den didaktiske trekanten (Håberg (2016: 63) etter Künzli (2000: 49)). 
Formidlingspedagogikk representerer eit balansert syn på aksen mellom personale og innhald, men med ei nedtoning av barna sine erfaringar og interesser som den tredje faktoren i ein pedagogisk situasjon. Formidlingspedagogikken blir kritisert for å legge for stor vekt på eit førehandsbestemt innhald i staden for interesser og erfaringar hos barna (Gundem 1998). Dette er ein type pedagogikk som barnehagen i liten grad har identifisert seg med, og som gjerne blir tolka å vere ein meir typisk skuleretta pedagogikk.

I kontrast til formidlingspedagogikken kan vekstpedagogikk kome til uttrykk ved at det blir lagt størst vekt på barnet i forhold til både innhald og personale (Håberg 2016; Künzli 2000). Vekstpedagogikk blir i teksten vidare definert som barnesentrert pedagogikk.

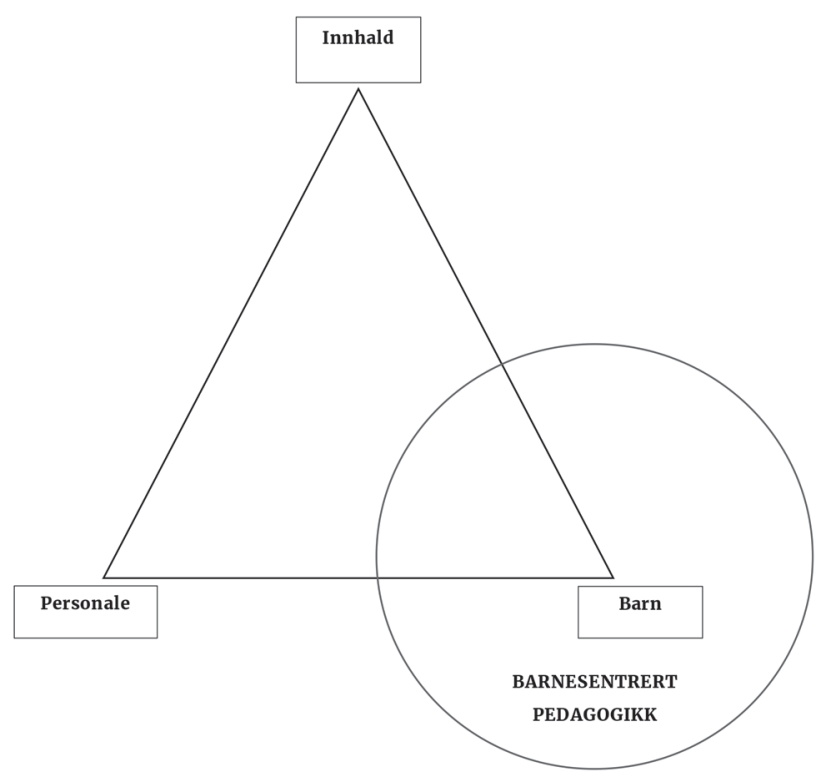

Figur 2 Barnesentrert pedagogikk med utgangspunkt i den didaktiske trekanten (Håberg (2016: 65) etter Künzli (2000: 49)).

Barnesentrert pedagogikk tyder at barnet sine erfaringar og interesser blir framheva før innhald og personale. Personalet sine innspel på innhaldsarenaen er i mindre grad relevante enn barnet sine eigne sjølvvalde aktivitetar og interessefelt. Rønning (2013: 53) peiker på at «I stedet for en aktiv, formidlende voksen ser man her for seg en mer passiv aktør som forsøker å skape et stimulerende miljø der barnet selv kan ta initiativ til egen læring og utvikling». 
Denne retninga møter kritikk mellom andre frå Skjervheim (1996), som hevdar at $\mathrm{i}$ ein pedagogisk situasjon må det $\mathrm{i}$ tillegg til ein subjekt-subjekt-relasjon mellom barnet og personalet også finnast ein tredje faktor. Sørbø (2004) introduserer med utgangspunkt i Skjervheim omgrepet pedagogikkens tredje, som i lys av den didaktiske trekanten vil seie at ein pedagogisk situasjon føreset ein innhaldsfaktor utanom interaksjonen mellom barn og personale. Det pedagogiske idealet er såleis eit balansert forhold mellom dei tre faktorane barn, innhald og personale i den didaktiske trekanten.

\section{Material, formal og kategorial danning}

Barnesentrert pedagogikk kan også definerast ut frå danningsteoriar. Material danningsteori viser til ei overtyding om at innhaldet eller substansen i opplæringa har kraft i seg sjølv til å utvikle danningsprosessar i individet (Hopmann 1997). Formal danningsteori definerer danning med utgangspunkt $i$ individet, og den er også innretta på metodiske aspekt som det å lære å lære (Gundem 1998). Det sentrale innhaldet er barna si eiga verksemd, interesser og erfaringar. Når formal danningsteori blir ståande aleine utan å bli supplert eller korrigert av material danningsteori, peikar den på sentrale trekk ved den barnesentrerte pedagogikken (Håberg 2016).

Ei syntese av formal og material danningsteori kjem til uttrykk i Klafki (1997) sitt omgrep kategorial danning. Dette bygger på ei både og tenking der barna tileignar seg viktige kategoriar eller omgrep som dei kan bruke til å forstå samfunn og kultur, samtidig som denne forståinga gjer at dei opnar seg opp for påverknad derifrå.

\section{HISTORISITET}

Kjennskap til historisitet kan ifølge Durkheim (1977: 9) styrke både våre forventningar til framtida og vår forståing av notida. Barnehagen som pedagogisk institusjon bygger på Fröbel, som ifølge Broström (2004) la vekt på alle dei tre faktorane i den didaktiske trekanten og på både formal og material danning. Etter Fröbel dreia barnehagepedagogikken seg gradvis mot stor vekt på barnas interesser og erfaringar, nedtoning av innhald, og personale som kanskje noko passive tilretteleggarar (Broström 2004). Dette tilsvarer ein barnesentrert pedagogikk. Så kva har skjedd med barnehagepedagogikken frå barnehagen vart oppretta i Tyskland i 1837 og fram til i dag? Eg vil vidare peike på trekk ved Fröbel sin pedagogikk som kan ha ført til at vi i dag kan seie at ein barnesentrert pedagogikk er del av barnehagen sin tradisjon.

Fröbel utvikla barnehagepedagogikken med bakgrunn i sin historiske kontekst, og han bygde på eksisterande teoriar utvikla av mellom andre Rousseau 
(Johansson 2004). Ein kan til dømes tenke seg at val av omgrepet og metaforen «barne-hage» kan peike tilbake på Rousseau si førestilling om barnet som skapt godt og som difor heller ikkje treng korreksjon. «Barne-hage» viser til eit område der barn skulle vere verna og trygt, som eit frø som får vekse i ein skjerma hage (Wallstrøm 1992). Implisitt blir då den vaksne si rolle å vatne frøet, luke vekk ugraset og la planta eller blomsten fă utfalde seg fritt.

Eit anna døme er dette med sjølvverksemd, at barnet handlar og er aktivt. Ifølge Bisgaard (2007) framheva Fröbel, lik Rousseau og Pestalozzi, at det er barnets eigen aktivitet som skaper utvikling. Dette finn ein også igjen seinare i reformpedagogikken, representert ved mellom andre Dewey og påstanden: learning by doing. Fröbel si vektlegging av barnets sjølvverksemd vart forsterka av reformpedagogikken og dreia over i to sentrale trekk som er typiske for ein barnesentrert pedagogikk: for det første i organisering og tidsbruk av barnehagen der frileik har blitt vurdert som svært sentralt, og for det andre i tilrettelegging av kreative aktivitetar (Bisgaard 2007). Frileik er $\emptyset$ kter på dagen då barna disponerer tida si sjølve og kan velje kva dei vil gjere på og kven dei vil vere saman med (Håberg 2016: 50).

Det er typisk for ein barnesentrert pedagogikk at utføring av kreative aktivitetar inneber lite bruk av instruksjon og av korreksjon, i tillegg til at barnet ikkje på nokon som helst måte skal bli tvinga eller pressa til aktivitetane (Broström 2004). Barnet si eiga verksemd skal vere styrt av barnet sjølv, vere lystbetont, gjerne oppstå spontant og i liten grad vere planlagt av personalet. Barnets nysgjerrighet, eigne erfaringar og førstehandsopplevingar er drivkraft for utvikling med frileiken som den ypparste aktiviteten. Arbeidsmåten er såleis «tilbakelent». Personalet er tilskodarar medan barna utfører kreative aktivitetar eller er i leik (Bisgaard 2007).

\section{Antiautoritær oppsedingstil}

Pedagogiske teoriar omhandlar meir enn forholdet mellom innhald, barn og personale slik den kjem til uttrykk i den didaktiske trekanten. Pedagogikk handlar også om oppseding i tydinga omsorg, stimulering og påverknad som den eldre generasjonen utøver overfor den yngre (Uljens og Mielityinen 2004). Ein har sett at barnehagepedagogikken blir påverka av nye retningar som oppstår i kultur og samfunn, som til dømes reformpedagogikken. Eg vil no skissere nokre linjer som gjeld oppseding som st $\emptyset$ ttar opp under den barnesentrerte pedagogikken og som både går bakover i tid før Fröbel og framover mot vår tid.

På 1900-talet finn ein retningar med radikal barnesentrering. Som døme gav Ellen Key (1912) rundt førre århundreskiftet ut boka Barnets århundre, der ho hevdar mellom anna at oppseding er å la naturen roleg og langsamt få hjelpe seg sjølv slik at forholda rundt barnet understøtter naturens eige arbeid. Ho meiner at eit anna 
ord for barn er «majestät» og at foreldre har like lite rett til å lage retningslinjer overfor eigne barn som dei har «makt och rätt att skriva dem för stjärnornas banor! » (Key 1912: 48-49). Dette vart fengande slagord i tida, med det frie, sterke og originale barnet som ideal. Også Alexander Neill, ein annen representant for barnesentrert pedagogikk, hevdar dette. Neill starta og leia Summerhillskulen frå 1924 og grunngav dette med at dei ville lage ein skule der barna skulle få lov til å vere seg sjølve, og «Derfor måtte lærarane gi avkall på all disiplin, all dirigering, på all moralsk og religiøs indoktrinering» (Neill 1965: 26).

Sjølv om dette kanskje er ytterpunkter av Key og Neill sine utsegner, viser dei likevel til eit barnesyn der barnet skal bli seg sjølv gjennom fråvær av autoritet og disiplin i oppsedinga, og gjennom sjølvleiing og opphøgd status. Dette liknar på Rousseau sitt barnesyn, som ein har sett tidlegare at også Fröbel var påverka av. Bisgaard (2007) hevdar at Rousseau stadig dukkar opp i 1960-åras antiautoritære oppgjer, og også i nyare debattar om sjølvregulering, sjølvorganisering, sjølvforvaltning og ansvar for eiga læring.

Denne korte gjennomgangen av retningar i kultur og samfunn peiker på ei barnesentrering som kan ha påverka pedagogikken i barnehagen. Barnet sin posisjon som subjekt er løfta opp. Det er viktig, men eg har også peika på at det kan føre til ei passiv vaksenrolle der barnet blir sett på som kompetent til å styre innhaldet i eigen lærings- og utviklingsprosess, dersom dette blir reindyrka.

Så langt har eg skrive som om pedagogiske retningar, som formidlingspedagogikk og barnesentrert pedagogikk, står fram i klart definert form ut frå vektlegging av ulike deler av den didaktiske trekanten (barn, innhald, personale). Men er det slik i røynda? Eg vil vise eit døme frå eige forskingsarbeid som peiker mot at det like gjerne kan førekome hybride former for pedagogisk praksis.

\section{HYBRID PRAKSIS}

Det empiriske datamaterialet i mitt doktorgradsarbeid bygger på ein kvalitativ studie i to barnehagar der eg observerte korleis åtte barnehagelærarar og assistentar leia og gjennomførte til saman 47 samlingsstunder og femårsklubbar (Håberg 2015). Femårsklubb tyder særskilde aktivitetar for barn siste året før skulestart. Eg tok del i aktiviteten medan eg tok notatar, og samtidig nytta leiaren for aktiviteten, enten det var barnehageleiar eller assistent, lydopptakar. Lydopptaka vart transkriberte på den måten at det berre var det som leiaren for aktiviteten sa, som vart skrive ned. Barna er ikkje informantar i studien.

Det viktigaste funnet når det gjeld samlingsstund og femårsklubb, er at personalet i svært stor grad er dei som bestemmer tema og innhald i dei to vaksenleia aktivitetane. På samlingsstund la nokre av informantane i stor grad vekt på forteljing, dramatisering og høgtlesing. Det vart lite rom for barna sine 
innspel, og deira rolle var å sitte stille og lytte. Dette kan tolkast som uttrykk for formidlingspedagogikk. Det same gjeld på femårsklubb, der barna fekk i oppgåve å teikne objekt som personalet hadde bestemt på førehand, som til dømes edderkopp eller seg sjølve («kroppen min»).

I kontrast var det andre informantar som i tydeleg større grad nytta spørsmål til barna slik at innhaldet i aktiviteten vart sentrert rundt barna sine ytringar og synspunkt. Personalet kom med få bidrag som kunne tilføre eller utvide barnas perspektiv. Dette kan likne barnesentrert pedagogikk, men spørsmåla til barna var i stor grad lukka og handla om det temaet som personalet hadde førehandsbestemt. Det vart såleis skapt forventning om eit innhald som spørsmålsstillaren kjende til. Følgande observasjon kan stå som døme :

Barna får på samlingsstund utdelt kvart sitt biletkort og blir etter tur spurde om kva som er på biletet. Tema på samlingsstunda er utifrå personalet sine planar barn i India. Nokre av bileta er av dyr, og barna sine svar blir kopla til India som i desse døma: «Kanskje der er elefantar i India» og «(...) kanskje der bur apar i India?» (Informant, Håberg 2015).

Temaet dyr kan vere fengande for mange barn, men vart med ein gong relatert til personalet sin tematikk slik at barna ikkje fekk høve til å fortelje om eigne erfaringar og opplevingar med dyr. Eg undrast over om dette inneber ei kamuflert form for formidlingspedagogikk fordi innhaldet er bestemt av personalet, men skjult for barna.

Studien viser at pedagogiske retningar ikkje treng opptre i reindyrka form, men kan førekome som hybridar. Sidan doktorgradsarbeidet er av kvalitativ karakter, kan eg ikkje seie noko om utbreiinga til hybride pedagogiske retningar (Maxwell 1992), men funna er ein indikator på at dei er til stades på barnehagefeltet.

\section{Drøfting}

Artikkelen bygger på føresetnaden at kva type pedagogikk barn møter i barnehagen, ikkje er uvesentleg for barna. Dessutan gjeld kva type pedagogikk barn møter i barnehagen, mange barn. Barnehagen er no blitt det vanlege ved norsk barndom, og omlag $90 \%$ av barnepopulasjonen i alderen eitt til fem år har barnehageplass. Det vil med 2016-tal seie nesten 287000 barn (SSB 2017). Dette er den fasen i livet der hjernen er mest plastisk og formbar, og det blir lagt eit fundamentalt grunnlag for resten av livet med omsyn til utvikling og læring av område som språk, kognisjon, motorikk og sosialisering (Hagtvet 2004; Tetzchner 2012).

Barnesentrert pedagogikk sin styrke kan vere eit tydeleg fokus på barn som subjekt i eigne liv. Gjennomgangen av barnehagepedagogiske idear og antiautoritære oppsedingsideal viser at typiske trekk ved ein barnesentrert pedagogikk 
er trua på at barnet har eit ibuande potensiale som må få utvikle seg og kome til uttrykk. Det er rom for å drøfte fleire aspekt ved denne pedagogiske retninga.

\section{Narsissistiske tendensar}

I ein barnesentrert pedagogikk blir barnets sjølv løfta fram, det er i det potensialet for læring og utvikling ligg. Denne retninga innanfor pedagogikken oppstod som ein reaksjon mot rådande oppfatningar av barnet som «becomings» og ikkje «beings», og i ei tid med sterke føringar for barnets plass i familien, kulturen og samfunnet. Reformpedagogikken kan ein til dømes sjå som ein reaksjon mot ein stivbeint metodikk i skulen der læraren hadde stor autoritet (Myhre 1996). Å løfte fram barnets eigenverdi og la det ta plass gjennom å vektlegge barnets potensiale, kan verke både rett og rimeleg ut frå denne historiske konteksten.

Men kva konsekvensar kan ein barnesentrert barnehagepedagogikk ha for barn i vår tid? Hargreaves (1996) peiker på samanhengar mellom utvikling av identitet og typiske trekk ved vår samtid som kritikk av tradisjonar, dekonstruksjon av rådande ideologiar og det Lyotard kallar dei store forteljingane. Dette kan ha ført til tap av kulturell og etisk ballast. Tradisjonelle slektsband er vikande, moralsyn, religiøse og ideologiske oppfatningar er mangfaldige, pluralistiske og flytande. Sjølvet har ingen røter i stabile relasjonar, ingen forankring i moralske kjensgjerningar og forpliktingar utanom seg, seier Hargreaves (1996: 85). Sjølvet må stadig skapast og bli stadfesta på nytt, og blir difor ein storleik utan substans og sentrum. Dette kan vere ei kjelde til kreativitet, myndiggjering og endring men også til usikkerheit, sårbarheit og sosial tilbaketrekking. Også Taylor (1998) peikar på negative konsekvensar av ei postmoderne forståing av sjølvet der autentisitet, det å realisere det eigentlege sjølvet, har blitt formålet med livet.

Hargreaves (1996: 83) spør om det postmoderne jaget etter sjølvoppfylling fører til ein aukande narsissistisk kultur i heile samfunnet. Med narsissisme meiner han noko meir enn sjølvsentrering, narsissisme omfattar også sjølvnyting og illusjonar om allmakt fordi vi møter få grenser og frustrasjonar. Det er etter mitt syn rom for å drøfte om ein barnesentrert pedagogikk i vår tid kan forsterke narsissistiske tendensar og skape utryggheit for barn og unge i deira identitetsutvikling.

\section{Skjult vaksenstyring}

Barnesentrert pedagogikk tar for gitt at barnet har tilstrekkeleg kompetanse inni seg til å meistre både frileik og kreative aktivitetar slik at instruksjon og korreksjon knapt er nødvendig. Men det kan vere relevant å drøfte i kva grad frileik og kreative aktivitetar er verkeleg frie og barnestyrte i lys av at personalet har bestemt rammefaktorar som kva tidspunkt på dagen dette skjer, korleis 
barna skal grupperast, fordeling av personalet og tilgang til materiell og leiketøy. Denne skjulte tilrettelegginga legg føringar for barnets sjølvverksemd slik at frileik og kreative aktivitetar er meir vaksenstyrte enn kva ein ser på overflata.

Tullgren (2003: 112), som i sitt doktorgradsarbeid unders $\emptyset$ ker leiken i barnehagen når personale deltek, hevdar at leik er ein «företeelse där idén om det fria och aktiva barnet ska förverkligas». Samtidig blir uønska element i leiken som å springe, rope høgt eller å bruke «våpen» regulert bort av personalet. Reguleringa skjer ikkje direkte gjennom straff eller skjenn, men indirekte gjennom å ta del i leiken samen med barnet og introdusere andre tema og materiell. Tullgren (2003) spør om dette får personalet til å tru at det skjer ei auka demokratisering i forholdet til barna.

Det er mulig det er trekk av det same i empirien eg refererte ovanfor (Håberg 2015), der omfattande bruk av spørsmål til barna gir inntrykk av barnesentrering. Men sidan spørsmåla skal føre fram til eit førehandsbestemt og vaksenstyrt innhald, inneber det ei skjult vaksenstyring som treng å bli løfta fram og diskutert på barnehagefeltet.

\section{Innhaldet sin plass og verdi}

Eit anna perspektiv eg vil drøfte, er innhaldet sin plass og verdi i barnehagepedagogikken. Vektlegginga av at innhaldet må ha sitt opphav i barnet, kan kritiserast med tanke på sosial utjamning. Politisk blir barnehagen sett på som ein sentral arena for å redusere sosial ulikskap (Meld. St. 19 (2015-2016)). Den barnesentrerte pedagogikken kan føre til at personalet i liten grad formidlar eit innhald til barnet utover det barnet sjølv viser interesse for. Til dømes kan då barn som heime blir lese til og får del i varierte aktivitets- og kunnskapsområde, i større grad enn barn som veks opp under andre vilkår, ha føresetnader for å kjenne igjen og ta del i aktivitetar dei møter i barnehagen. Ei tydeleg vektlegging av at barn skal velje, kan føre til at dei takkar nei til for eksempel høgtlesing som vi veit kan ha stor verdi for barns omgrepsutvikling og seinare leseferdigheiter. Det vil seie at ein aktivitet som kan fremje læring hos barnet, blir unngått med grunngjevingar som at barnet har ikkje lyst, eller at det ikkje er interessert. Kanskje blir også barns medverknad (Kunnskapsdepartementet 2017) nemnd.

Eit anna moment som gjeld innhald, er at personalet sitt bidrag kan styrke barnet. Den barnesentrerte pedagogikken si vektlegging av at innhaldet må ha sitt opphav i barnet, kan gi barn færre erfaringar og interesser enn det elles ville ha hatt. Ei slik vektlegging av formal danning kan hindre barna i å tileigne seg kategoriar og omgrep om verda, og motverke det Klafki (1997) viser til som kategorial danning. Eit innhald som er meir enn det barnet kjenner til frå før, kan biletleg tala vere som eit vindauge som blir opna opp og som fører til at barnet ser og erfarer noko det elles ikkje ville ha gjort. Haram (2009) nyttar 
denne metaforen om kunsten sin plass i moderne samfunn. Han seier at når fortolking blir viktigare enn det som skal fortolkast, og kunsten ser seg sjølv ikkje berre som subjekt, men som objekt, blir kunst lik «speglar som dannar glasfelt i rommet. Der ein før såg ut, på ein faktisk røyndom, ser ein no berre seg sjølv» (Haram 2009:18).

Når vi ser inn i ein spegel, ser vi oss sjølve som fyller ruta. Det er grunn til å drøfte om denne sjølvsentreringa kan støtte opp under narsissistiske tendensar. Spørsmålet er om barnehagen kan fungere som eit vindauge som opnar opp omverda for barna, og på den måten formidlar kulturelle verdiar som er vesentlege i vårt demokrati. Dette er spørsmål å ta med seg vidare.

\section{IMPLIKASJONAR OG VEGEN VIDARE}

Denne artikkelen har unders $\emptyset \mathrm{kt}$ problemstillinga Kva kjenneteiknar barnesentrert pedagogikk $i$ barnehagen, og kva konsekvensar kan denne pedagogiske retninga ha i vår tid? Barnesentrert pedagogikk er definert og belyst teoretisk og historisk og eksemplifisert empirisk for å vise til kjenneteikn og konsekvensar av denne pedagogiske retninga.

Eg starta artikkelen med å vise til at barnesentrert pedagogikk kan vere eit negativt lada omgrep. Eg har peika på at noko av årsaken kan vere at den gir barn eit for stort ansvar for eiga læring og utvikling, og at dette kan vere særleg sårbart i den postmoderne tidsalderen med flytande rammer i kultur og samfunn rundt barnet. Allereie i 1927 hevda Thomas Litt at ein negativ konsekvens av barnesentreringa i pedagogikken kan vere utvikling av subjektivisme, noko som ikkje blir kritisert gjennom objektivistiske korrektiv (Litt 1927). Den barnesentrerte pedagogikken der korreksjon og også instruksjon i liten grad har status, kan såleis forsterke tendensar til ein sjølvsentrert kultur.

I lys av danningsteoriar, slik dei kjem til uttrykk i den didaktiske trekanten og Klafki sitt omgrep kategorial danning, er det nødvendig med eit personale i barnehagen som både følger barna sine initiativ, men som også utvider eksisterande interesser og motiverer til å opne seg opp for noko nytt og ukjent (Hopmann 1997; Klafki 1997; Künzli 2000). Den nyaste rammeplanen på barnehagefeltet understreker nettopp dette ansvaret. Personalet skal både «oppdage, følge opp og utvide det barna allerede er opptatt av» og «introdusere nye perspektiver og tilrettelegge for nye opplevelser og erfaringar» (Kunnskapsdepartementet 2017: kapittel 8). Dette føreset etter mitt syn ei aktiv vaksenrolle frå personalet si side. Ein må ikkje gløyme at barn er ulike, nokre meistrar godt sjølvregulering, sjølvaktivitet, frileiken og sjølvorganiseringa. Men for nokre barn er til dømes frileiken det mest krevjande dei opplever i barnehagen, kontra vaksenleia aktivitetar og kvardagssituasjonar som har faste rammer og ofte eit script som 
blir følgt (Statped 2015). For nokre barn kan dette gi tryggheit; vaksne som bestemmer, som lager rammer, som støtter i leiken, er «på», og som ikkje overlater til barnet å ha ansvar for innhaldet i sin eigen kvardag.

Sjølv om den barnesentrerte pedagogikken ikkje er eit lysande ideal, har den nokre sentrale poeng. Den kan inspirere til at barnehagefeltet arbeider for og oppmuntrar kvarandre til å vere sterkt barneorienterte. Eg meiner barnehagen skal primært vere til for barn, på barns premissar. Ein barnesentrert pedagogikk minner oss på at barn er subjekt, ein eigen person, og ikkje eit objekt for vår pedagogiske praksis. Samtidig er det svært problematisk dersom pedagogikken gjer at barn ikkje får tilstrekkeleg støtte og eit innhald som går utover barnet sjølv. Barn skal bli elska, ikkje forguda. Dei treng personale i barnehagen som både støttar og stiller krav, og som ikkje abdiserer frå ansvar og oppgåver som vaksne skal ha. Barnesentrert pedagogikk kan ha som konsekvens å motverke eit likeverdig pedagogisk tilbod for alle barn og å støtte opp under ei sjølvsentrert, narsissistisk livsoppfatning. Barnehagepedagogiske retningar må difor undersøkast empirisk og utviklast teoretisk for å sikre barns beste no og i framtida.

\section{LITTERATUR}

Bae, Berit. 2016. $\AA$ se barn som subjekt - noen konsekvenser for pedagogisk arbeid $i$ barnehage. [online] Tilgjengeleg: https://www.regjeringen.no/no/tema/familie-og-barn/barnehager/artikler/a-se-barn-som-subjekt---noen-konsekvense/ id440489/

Bisgaard, Niels Jørgen. 2007. «Om pædagogiske teoriers indflydelse på pædagogikken i folkeskolen og i daginstitutioner for børn» i Niels Jørgen Bisgaard \& Jens Rasmussen (red.), Pædagogiske teorier (s. 276-293). Værløse: Billes $\emptyset$ og Balzer.

Broström, Stig. 2004. «Pædagogiske læreplaner i børnehaven» i Stig Broström (red.), Pœdagogiske læreplaner. At arbejde med didaktik i børnehaven (s. 27-48). Århus: Systime Academic.

Drugli, May Britt. 2014. Liten i barnehagen. Forskning, teori og praksis. Oslo: Cappelen akademisk.

Durkheim, Emile. 1977. The Evolution of Educational Thought. London, Henley and Boston: Routledge \& Kegan Paul.

Gundem, Bjørg Brandtzæg. 1975. Tradisjon-kritikk-syntese. En analyse av hovedtrekk ved samtidig tysk didaktikk - med en relatering til aktuelle spørsmål i nordisk sammenheng. (Hovudfagsoppgåve), Universitetet i Oslo, Oslo.

Gundem, Bjørg Brandtzæg. 1998. Skolens oppgave og innhold. En studiebok i didaktikk. Oslo: Universitetsforlaget.

Hagtvet, Bente Eriksen. 2004. Språkstimulering. Tale og skrift i førskolealderen (2. utg.). Oslo: Cappelen Akademisk Forlag. 
Haram, Arnfinn. 2009. «Den estetiske spegelsalen» i Arnfinn Haram \& Jon Michelet (red.), Tre florentinarar. Essay og artiklar om religion, kultur og samfunn: 2003-2009 (s. 17-22). Follese: Efrem forlag.

Hargreaves, Andy. 1996. Lœrerarbeid og skolekultur. Lœreryrkets forandring i en postmoderne tid. Oslo: Ad Notam Gyldendal.

Hopmann, Stefan. 1997. «Wolfgang Klafki och den tyska didaktiken» i Michael Uljens (red.), Didaktik (s. 198-214). Lund: Studentlitteratur.

Håberg, Liv Ingrid Aske. 2015. Didaktisk arbeid i barnehagen. Kvalitativ studie av korleis assistentar og barnehagelærarar planlegg, gjennomfører og vurderer samlingsstund og femårsklubb. (Doktorgradsavhandling), Universitetet i Oslo, Oslo.

Håberg, Liv Ingrid Aske. 2016. Kvardagslivets didaktikk. Ansvar og arbeidsfordeling. Oslo: Universitetsforlaget.

Johansson, Jan-Erik. 2004. «Friedrich Wilhelm August Fröbel. Fritt tänkande och samhandlande barn» i Kjetil Steinsholt \& Lars Løvlie (red.), Pedagogikkens mange ansikter. Pedagogikkens idéhistorie fra antikken til det postmoderne (s. 260-273). Oslo: Universitetsforlaget.

Key, Ellen. 1912. Barnets århundrade. Studie av Ellen Key II. Stockholm: Albert Bonniers Förlag.

Klafki, Wolfgang. 1997. «Kritisk-konstruktiv didaktik» i Michael Uljens (red.), Didaktik (s. 215-228). Lund: Studentlitteratur.

Kunnskapsdepartementet. 2005. Lov om barnehager, LOV-2005-06-17-64. [online] Tilgjengeleg: https://lovdata.no/dokument/NL/lov/2005-06-17-64

Kunnskapsdepartementet. 2017. Rammeplan for barnehagens innhald og oppgåve. Oslo: Kunnskapsdepartementet. [online] Tilgjengeleg: https://lovdata.no/dokument/ SF/forskrift/2017-04-24-487

Künzli, Rudolf. 2000. «German Didaktik. Models of Re-presentation, of Intercourse, and of Experience» i Ian Westbury, Stefan Hopmann \& Kurt Riquarts (red.), Teaching as a reflective practice. The German didaktik tradition (s. 41-54). Mahawah, N.J.: Lawrence Erlbaum Associates.

Lindensjö, Bo \& Lundgren, Ulf P. 2000. Utbildningsreformer och politisk styrning. Stockholm: HLS förlag.

Litt, Thomas. 1927. Führen oder Wachsenlassen. Stuttgart: Ernst Klett.

Maxwell, Joseph. 1992. «Understanding and Validity in Qualitative Research» i Harvard Educational Review, 62(3), 279- 300.

Meld. St. 19. 2015-2016. Tid for lek og loering. Bedre innhold $i$ barnehagen. Oslo: Kunnskapsdepartementet. [online] Tilgjengeleg: https://www.regjeringen.no/no/ dokumenter/meld.-st.-19-20152016/id2479078/

Myhre, Reidar.1996. Grunnlinjer i pedagogikkens historie. Oslo: Ad Notam Gyldendal. Neill, Alexander Sutherland. 1965. Summerhill. Radikal barneoppdragelse. Oslo: Pax. 
Rønning, Grethe Steen. 2013. Rammeplan for barnehagen, hva så? Oslo: Cappelen Damm Akademisk.

Skjervheim, Hans. 1996. Deltakar og tilskodar og andre essays. Oslo: Aschehoug.

Solberg, Per. 2002. 《Lærerskolen 100 år» i Norsk pedagogisk tidsskrift, 86 (2/3), s. 97-110.

SSB. 2017. Barnehager, 2016, endelige tall. [online] Tilgjengeleg: https://www.ssb.no/ utdanning/statistikker/barnehager/aar-endelige/2017-03-21

Statped. 2015. Fokus på tidlig innsats. [online] Tilgjengeleg: http://www.statped.no/ Global/L\%C3\%A6ringsressurs/Dokumenter/Tiltak-for-Fokus-paa-tidlig.innsats. pdf

Sørbø, Jan Inge. 2004. «Hans Skjervheim og pedagogikkens tredje» i Harald Thuen \& Sveinung Vaage (red.), Pedagogiske profiler. Norsk utdanningstenkning fra Holberg til Hernes (s. 303-319). Oslo: Abstrakt forlag.

Taylor, Charles. 1998. Autentisitetens etikk. Oslo: Cappelen akademisk forlag.

Tetzchner, Stephen von. 2012. Utviklingspsykologi. Oslo: Gyldendal Akademisk.

Tullgren, Charlotte. 2003. Den välreglerade friheten. Att konstruera det lekande barnet. (Doktorgradsavhandling), Lärarutbildningen: Malmö högskola.

Uljens, Michael \& Mielityinen, Mari. 2004. «Friedrich Daniel Ernst Schleiermacher» i Kjetil Steinsholt \& Lars Løvlie (red.), Pedagogikkens mange ansikter. Pedagogikkens idéhistorie fra antikken til det postmoderne. Oslo: Universitetsforlaget.

Wallström, Birgitta. 1992. Möte med Fröbel. Lund: Studentlitteratur.

$\emptyset$ strem, Solveig. 2012. Barnet som subjekt. Etikk, demokrati og pedagogisk ansvar. Oslo: Cappelen Damm. 